\title{
A Study on Problems and Needs of Rural Youths Practicing Farming in Jorhat district of Assam, India
}

\author{
Moromi Buragohain ${ }^{1 *}$, Nagen Bordoloi ${ }^{1}$ and Inne Lego ${ }^{2}$
}

${ }^{1}$ Department of Extension Education, Assam Agricultural University, Jorhat-13, Assam, India

${ }^{2}$ Department of Extension Education, College of Post Graduate Studies, CAU, Meghalaya, India

*Corresponding author

\section{A B S T R A C T}

The study entitled "Problems and Needs of Rural Youths Practising Farming in Jorhat district of Assam" was carried out in Jorhat district of Assam with a total of 200 respondents using multistage purposive cum random sampling technique. The data were

\section{Keywords}

Rural youths,

Problems, Needs,

Farming

Article Info

Accepted:

20 January 2018

Available Online:

10 February 2018 collected by means of personal interview and structured schedule during $25^{\text {th }}$ Feb, 2016 $3^{\text {rd }}$ April, 2016. The findings revealed that the lack of proper knowledge in agriculture/technical know-how $(87.00 \%)$ was expressed as the most serious problem followed by complex process of credit facilities (80.50\%). Also problems of timely information/advice (77.00\%), irrigation problem $(67.00 \%)$ and lack of adequate fund $(65.50 \%)$ were some of the major problems of rural youths in practising farming. Regarding needs promoting youth's involvement in community decision making relating to agriculture development $(99.00 \%)$ was mentioned as the most urgent need of rural youths followed by enhancing intensive network of extension agents for motivation and training of rural youths for agri preneurship development (98.00\%). Also needs of adequate subsidy of loan for farm implements and inputs $(97.50 \%)$, skills related to agriculture in using new technology $(95.00 \%)$, availability of inputs in time $(93.50 \%)$, improving access to amenities like electricity, irrigation etc. $(93.00 \%)$ were some of the most important needs of the rural youths who are practising farming.

\section{Introduction}

Rural youth are the future of food security. Yet around the world, few young people see a future for themselves in agriculture or rural areas. Rural youth face many hurdles in trying to earn a livelihood. Pressure on arable land is high in many parts of the world, making it difficult to start a farm. Sharma (1994) from her study found that lack of irrigation facilities, high cost of inputs and plant protection chemicals, lack of credit facilities etc. were the major problems faced by the rural youths in taking up farming occupation. While most of the world's food is produced by (ageing) smallholder farmers in developing countries, older farmers are less likely to adopt the new technologies needed to sustainably 
increase agricultural productivity, and ultimately feed the growing world population while protecting the environment. Hence, we need to re-engage youth in agriculture. According to Ruta (2012) the participation of youth in agriculture became a problem in the country since the time of the introduction of Structural Adjustment Programs in 1980s. Youth have been more disenchanted with agricultural activities due to the diversity of non-agricultural activities as a result of privatization and free market economy. Though youth have desirable qualities that can promote agriculture, most of them have strong apathy toward it.

This has resulted in mass unemployment and lack of sustainable livelihood among youth. With fewer youth into agriculture, the long term future of agriculture sector is in question (Chikezie, 2012). Young people living in rural areas are forced to migrate to cities as they do not find enough incentives, profitable economic opportunities and attractive environments in rural areas. Poor policies coupled with poor performance of the sector itself have led to youth's disinterest in agriculture sector despite of its available opportunities. Also lack of rural credit, unemployment, rural poverty, weak profitability of the sector and capacity constraints are perceived to be the factors which hinder youth participation in agricultural activities in rural areas (Akpan, 2010).

Rutta (2012) shows that the perceptions of greater job opportunities, poor physical infrastructure and social amenities in rural areas and general dislike of village life to be the factors for youth participation in agriculture. Also the awareness of agricultural initiatives to youth is very low and for them agriculture is unprofitable business which is supposed to be done by the old, retired or for those who lack other alternatives. Rural youth identified a wide range of problems and needs associated with agriculture as a chosen career; series of problems and needs are militating against active participation of rural youth in agricultural production activities in the study area. So, emerging youth in agriculture strategy must demonstrate a clear understanding of the youth's affinity for technology, efficiency and a strong voice in the decision-making processes. The strategy must also lay emphasis on the need for the incorporation of agriculture in the regular curriculum (Onwubiko, 2011). Therefore this study was conducted on identifying the problems and the needs of rural youth practising farming in Jorhat district of Assam.

\section{Materials and Methods}

The population of the study comprised the rural youths in the study area that were engaged in farm operation during the study. Jorhat district was purposively selected for the present study.Two sub-division viz. Jorhat and Titabor were selected randomly from Jorhat district. Two A.D.O. circles from each sub division were selected randomly. These were Dhekorgorah and Teok A.D.O. circles under Jorhat sub-division and Madhapur and Baghchung A.D.O. circles under Titabar subdivision were selected randomly. Two villages from each A.D.O. circle were selected randomly for the present study.

Thus altogether there were eight randomly selected villages. Hence a total of 200 rural youths were sampled. After reviewing the relevant literature and consulting extension personnel working in the study area, some problems and needs related to taking up farming occupation were selected. To identify these problems and needs the respondents were asked both structured and open ended questions and their frequency, percentage were calculated and then ranking was done on basis of the size of percentage. 


\section{Results and Discussions}

The data presented in Table 1 reveal that the lack of proper knowledge in agriculture/technical know-how $(87.00 \%)$ was expressed as the most serious problem followed by complex process of credit facilities $(80.50 \%)$. It was evident from the table that problems of timely information/advice $\quad(77.00 \%)$, irrigation problem $(67.00 \%)$, lack of adequate fund $(65.50 \%)$ were some of the major problems of rural youths in practising farming. The finding was similar to the finding of Dutta (1999) and Nath (2001). The data presented in Table 5.2 reveal that promoting youth's involvement in community decision making relating to agriculture development (99.00\%) was mentioned as the most urgent need of rural youths in practising farming followed by enhancing intensive network of extension agents for motivation and training of rural youths for agri preneurship development (98.00\%).

It was evident from the table that needs of adequate subsidy of loan for farm implements and inputs $(97.50 \%)$, skills related to agriculture in using new technology $(95.00 \%)$, availability of inputs in time $(93.50 \%)$, improving access to amenities like electricity, irrigation etc. (93.00\%) were some of the most important needs of the rural youths who are practising farming.

Table.1 Distribution of respondents on basis of problems faced in practicing farming (In descending order)

\begin{tabular}{|c|l|c|c|c|}
\hline Sl. No. & \multicolumn{1}{|c|}{ Problems } & $f$ & $\%$ & Rank \\
\hline $\mathbf{1}$ & Lack of proper knowledge in technical know-how & 174 & 87.00 & I \\
\hline $\mathbf{2}$ & Complex process of credit facilities & 161 & 80.50 & II \\
\hline $\mathbf{3}$ & Problems of timely information/advice relating to agriculture & 154 & 77.00 & III \\
\hline $\mathbf{4}$ & Irrigation problem & 134 & 67.00 & IV \\
\hline $\mathbf{5}$ & Lack of adequate funds & 131 & 65.50 & V \\
\hline $\mathbf{6}$ & Unavailability of inputs in time & 109 & 54.50 & VI \\
\hline $\mathbf{7}$ & Lack of sufficient cultivable land & 96 & 48.00 & VII \\
\hline
\end{tabular}

Table.2 Distribution of the respondents according to their needs (in descending order)

\begin{tabular}{|c|l|c|c|c|}
\hline SI. No. & \multicolumn{1}{|c|}{ Needs } & $\boldsymbol{f}$ & $\mathbf{\%}$ & Rank \\
\hline $\mathbf{1}$ & $\begin{array}{l}\text { Promoting youths involvement in community decision } \\
\text { making relating to agriculture development }\end{array}$ & 198 & 99.00 & I \\
\hline $\mathbf{2}$ & $\begin{array}{l}\text { Enhancing intensive network of extension agents for } \\
\text { motivation and training of rural youths for agripreneurship } \\
\text { development }\end{array}$ & 196 & 98.00 & II \\
\hline $\mathbf{3}$ & Adequate subsidy of loan for farm implements and inputs & 195 & 97.50 & III \\
\hline $\mathbf{4}$ & Skills related to agriculture in using new technology & 190 & 95.00 & IV \\
\hline $\mathbf{5}$ & Availability of inputs in time & 187 & 93.50 & V \\
\hline $\mathbf{6}$ & Improving access to amenities like electricity, irrigation etc. & 186 & 93.00 & VI \\
\hline $\mathbf{7}$ & Easy access to credit and funding & 166 & 83.00 & VII \\
\hline $\mathbf{8}$ & Land availability & 137 & 68.50 & VIII \\
\hline $\mathbf{9}$ & Labour availability & 134 & 67.00 & IX \\
\hline
\end{tabular}




\section{Conclusion and implications of the findings}

Most of the rural youths do not see a prosperous future in agricultural sector and this may be due the reason of low availability of land, lack of rural credits, lack of technology and training related to agriculture and mostly because of lack of profitability of agricultural activities and lack of physical and social infrastructure in rural areas.

All the above mentioned needs are necessary in order to reduce rural-urban migration and keep youths in rural areas as well as promote their interests in agriculture.

Efforts should be made to integrate the views of youths into developmental efforts in order to address the actual needs of the youths, thus making agricultural development planning and management sensitive to their needs. The government should reform and formulate the development policies which are in favour for rural youth participation in agricultural activities. The government should ensure the availability of enough inputs and capital for rural youth.

This will improve rural economy as well as reducing the rate of youth migration from rural areas to urban areas. Also rural youth should organize themselves in groups in order to share knowledge and experience for the improvement of agriculture production.

This will also help them to secure loans from micro and macro credit institutions. Rural youth should know that they are the important asserts for agriculture and rural development.

The government should provide more sensitization programs for rural youth participation for their awareness on agriculture and their development. Given the opportunity, organization, direction and support, rural youth can participate and contribute significantly to agricultural and rural development.

\section{References}

Akpan, S. B. (2010). Encouraging youths involvement in agricultural production and processing. Nigeria Strategy Support Program, Policy Note No. 29. International Food Policy Research Institute, Nigeria Office, Abuja, pp. 1-4.

Chikezie, N. P.; Chikaire J.; Osuagwu, C. O.; Ihenacho, R. A.; Ejiogu, N.; Oguegbuchulam, M. N. and Obi, K.U. (2012). Factors constraining rural youths involvement in Cassava production in Onu - Imo local government area of Imo State, Nigeria. Global Advanced Res. J. Agril. Sci. 1(8): 223-232.

Dutta, P. (1999). “A study on the participation of rural youth in winter vegetables cultivation practices in Jorhat district of Assam". M.Sc. Thesis, Dept. of Extension Education, AAU.

Nath, D. (2001). A study on the extent of participation on selected rural youth club members in different rice cultivation practices in Jorhat district of Assam. M.Sc. (Agril), thesis, AAU, Jorhat.

Onwubiko, M. (2011). Entrepreneurship and leadership: Nigeria and the imperative for youth entrepreneurial development. Universal J. of Edu. and General Studies, 1(3): 55-70.

Ruta, E. (2012). Current and emerging youths policies and initiatives with a special focus and links to agriculture Tanzania (mainland) case study draft report. RUTTA: South Africa, p. 5.

Sharma, A. (1994)). "A study on the attitude of the rural youth and their extent of participation in farming" M.Sc. Thesis of Extn. Edu, AAU.

\section{How to cite this article:}

Moromi Buragohain, Nagen Bordoloi and Inne Lego. 2018. A Study on Problems and Needs of Rural Youths Practicing Farming in Jorhat district of Assam, India. Int.J.Curr.Microbiol.App.Sci. 7(02): 21982201. doi: https://doi.org/10.20546/ijcmas.2018.702.264 